\title{
Three-level Local Thresholding Berbasis Metode Otsu untuk Segmentasi Leukosit pada Citra Leukemia Limfoblastik Akut
}

\author{
Eka Prakarsa Mandyartha ${ }^{1}$, Chastine Fatichah ${ }^{2}$ \\ Program Studi Teknik Informatika, Fakultas Teknologi Informasi, Institut Teknologi Sepuluh Nopember \\ Kampus ITS Keputih, Sukolilo, Surabaya, 60111, Jawa Timur \\ E-mail: ${ }^{1}$ ekaprakarsa@gmail.com, ${ }^{2}$ chastine@cs.its.ac.id
}

Masuk: 13 Juli 2015; Direvisi: 30 Juli 2015; Diterima: 30 Juli 2015

\begin{abstract}
Segmentation of Acute Lymphoblastic Leukemia (ALL) images can be used to identify the presence of ALL disease. In this paper, three-level local thresholdings based on Otsu method is presented for leucocytes segmentation in ALL image. Firstly, a method based on Gram-Schmidt orthogonalization theory is applied to partition the input image into several sub-images. The proposed method extends Otsu's bi-level thresholding to three-level thresholding method to find two local threshold values that maximize betweenclass variance. Using the two local threshold values and three-level local thresholding technique then segmenting each of sub-images into three regions, e.g. nucleus, cytoplasm, and background. To evaluate the performance of the proposed method, 32 peripheral blood smear images are used. The performance of the proposed method is compared with manually segmented ground truth using Zijdenbos similarity index (ZSI), precision, and recall. An experimental evaluation demonstrates superior performance over three-level global thresholding for ALL image segmentation.
\end{abstract}

Keywords: three-level local thresholding, acute lymphoblastic leukemia, three-level Otsu thresholding, gram-schmidt orthogonalization

\begin{abstract}
Abstrak. Segmentasi citra Limfoblastik Leukemia Akut (LLA) dapat digunakan untuk mengidentifikasi kehadiran penyakit LLA. Pada penelitian ini diusulkan metode threelevel local thresholding berbasis metode Otsu untuk segmentasi leukosit pada citra LLA. Pertama-tama, metode berbasis teori ortogonalisasi Gram-Schmidt diaplikasikan untuk membagi citra LLA menjadi sub-sub citra. Metode yang diusulkan memperluas metode bi-level thresholding Otsu ke dalam kasus three-level thresholding untuk pencarian dua nilai ambang lokal tiap sub-citra yang memaksimumkan varian antar kelas. Dengan nilai ambang jamak lokal tersebut, teknik three-level local thresholding selanjutnya mensegmentasi tiap sub-citra ke dalam tiga region, yaitu nukelus, sitoplasma, dan latar belakang. Untuk mengevaluasi performa metode usulan, 32 citra uji digunakan. Performa metode yang diusulkan dibandingkan dengan citra segmentasi manual menggunakan Zijdenbos similarity index (ZSI), presisi, dan recall. Hasil uji coba menunjukkan performa three-level local thresholding lebih unggul daripada metode three-level global thresholding untuk segmentasi citra LLA.
\end{abstract}

Kata Kunci: three-level local thresholding, leukemia limfoblastik akut, three-level Otsu thresholding, ortogonalisasi gram-schmidt

\section{Pendahuluan}

Leukemia limfoblastik akut (LLA) merupakan penyakit leukemia akut yang ditemukan pada sel darah putih (leukosit) jenis limfosit. Kehadiran LLA ditandai oleh perbanyakan abnormal sel limfosit pada sumsum tulang (Larson, dkk., 2008). Pemeriksaan awal laboratorium dilakukan dengan mengobservasi morfologi leukosit secara manual untuk mendeteksi kehadiran LLA (Albitar, dkk., 2008). Observasi secara manual tersebut bergantung pada pengalaman ahli hematologi dan membutuhkan waktu yang lama. Oleh karena itu, sistem otomatis pengidentifikasi LLA dapat meningkatkan akurasi identifikasi dan mengurangi waktu yang dibutuhkan (Rezatofighi, dkk., 2011). Segmentasi leukosit merupakan tahap awal dan krusial dalam sistem otomatis pengidentifikasi LLA. Segmentasi leukosit bertujuan mengekstrak region 
nukleus dan sitoplasma dari objek lain, yaitu eritrosit dan latar belakang. Metode segmentasi leukosit yang akurat dibutuhkan untuk meningkatkan akurasi deteksi LLA.

Beberapa metode segmentasi leukosit telah diusulkan. Misalnya, (Piuri, dkk., 2004) mengkombinasikan metode deteksi tepi, dan filtering untuk mensegmentasi leukosit. (Madhloom, dkk., 2012) mengembangkan sistem otomatis untuk mensegmentasi leukosit pada citra LLA berbasis operasi morfologi citra biner. (Scotti, 2006), (Mohapatra, dkk., 2014), dan (Wang, dkk., 2009) memperkenalkan teknik image clustering untuk mengekstrak leukosit dari objek lainnya pada citra mikroskopis darah. Penelitian yang dilakukan oleh (Rezatofighi, dkk., 2011) menggabungkan metode ortogonalisasi Gram-Schmidt dan parametric deformable model untuk mensegmentasi leukosit. Metode Gram-Schmidt digunakan untuk mensegmentasi nukleus, sedangkan parametric deformable model diaplikasikan untuk mensegmentasi sitoplasma. (Fatichah, dkk., 2012) memperkenalkan metode segmentasi leukosit menggunakan skema interest-based ordering dalam operasi morfologi fuzzy pada citra grayscale. Pendekatan lain mengusulkan teknik thresholding untuk mensegmentasi leukosit. Teknik thresholding memisahkan objek yang diinginkan dari objek lainnya berdasarkan nilai ambang tertentu. (Putzu, dkk., 2014) mengembangkan sistem otomatis pengidentifikasi LLA. Segmentasi sitoplasma direalisasikan menggunakan metode segitiga Zack berbasis teknik bi-level thresholding. Kombinasi antara citra biner yang diperoleh dari komponen green pada ruang warna RGB dan citra biner yang diperoleh dari komponen a* pada ruang warna CIELab digunakan untuk mensegmentasi nukleus.

Single threshoding atau biasa disebut dengen bi-level thresholding, mengelompokkan piksel citra ke dalam dua region, yaitu objek dan latar belakang, berdasarkan sebuah nilai ambang. Berbeda dengan bi-level thresholding, teknik multilevel thresholding mengelompokkan piksel citra ke dalam lebih dari dua region yaitu objek-objek dan latar belakang menggunakan nilai ambang jamak, sehingga hasil segmentasinya lebih baik daripada bi-level thresholding. Namun demikian, multilevel thresholding merupakan metode global thresholding yang menentukan nilai ambang berdasarkan histogram semua piksel citra. Teknik tersebut tidak dapat digunakan pada semua kasus untuk mensegmentasi leukosit dengan baik. Bila piksel region leukosit hanya merupakan bagian kecil dari total piksel citra, maka akan terjadi kesalahan segmentasi. Teknik multilevel local thresholding lebih cocok untuk kasus tersebut karena nilai ambang ditentukan berdasarkan histogram masing-masing region citra.

Pada penelitian ini, teknik three-level local thresholding berbasis metode Otsu untuk segmentasi leukosit pada citra LLA diusulkan. Teknik three-level local thresholding adalah teknik multilevel local thresholding yang membagi citra ke dalam tiga level. Three-level local thresholding mempartisi citra LLA menjadi sub-sub citra. Tiap sub-citra berisi region leukosit. Metode berbasis teori ortogonalisasi Gram-Schmidt diaplikasikan untuk mempartisi citra LLA. Metode Otsu merupakan salah satu teknik bi-level thresholding terhandal (Gao, dkk., 2010) sehingga dipakai secara luas untuk mensegmentasi citra. Metode Otsu menyelesaikan permasalahan pemilihan nilai ambang menggunakan analisis diskriminan berdasarkan histogram citra. Nilai ambang memisahkan dua kelompok piksel dan ditentukan ketika varian antar dua kelompok tersebut maksimum. Metode yang diusulkan memperluas metode bi-level thresholding Otsu ke dalam kasus three-level thresholding untuk pencarian dua nilai ambang lokal tiap sub-citra yang memaksimumkan varian antar kelas. Dengan nilai ambang jamak lokal tersebut, teknik three-level local thresholding selanjutnya mensegmentasi nukleus dan sitoplasma tiap sub-citra.

\section{Segmentasi Leukosit}

Sistem otomatis pengidentifikasi LLA digunakan untuk membantu ahli hematologi mendeteksi kehadiran LLA dengan lebih mudah, akurat, dan cepat. Ada empat proses dalam sistem otomatis pengidentifikasi LLA yaitu segmentasi leukosit, ekstraksi fitur leukosit, dan klasifikasi LLA. Salah satu proses terpenting adalah segmentasi leukosit. Citra input pada sistem otomatis ini, biasanya, adalah citra mikroskopis sampel darah. Tahapan pertama, pada sistem otomatis pengidentifikasi LLA, menjadi fokus pada penelitian ini, yaitu proses 
segmentasi leukosit sehingga diperoleh region nukleus dan sitoplasma. Segmentasi leukosit yang mensegmen citra ke dalam dua region ditunjukkan pada Gambar 1. Region nukleus diindikasikan oleh warna hitam, sedangkan region sitoplasma diindikasikan pada warna keabuan.

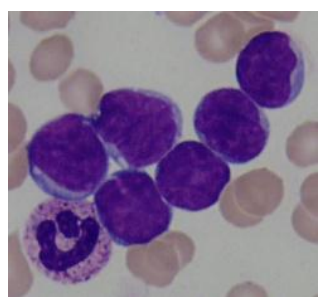

(a)

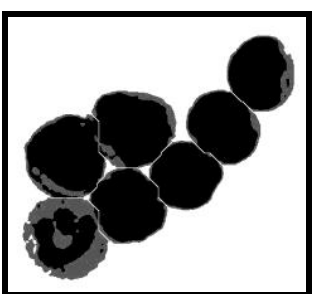

(b)

Gambar 1. Segmentasi leukosit (a) citra input (b) citra leukosit yang tersegmentasi

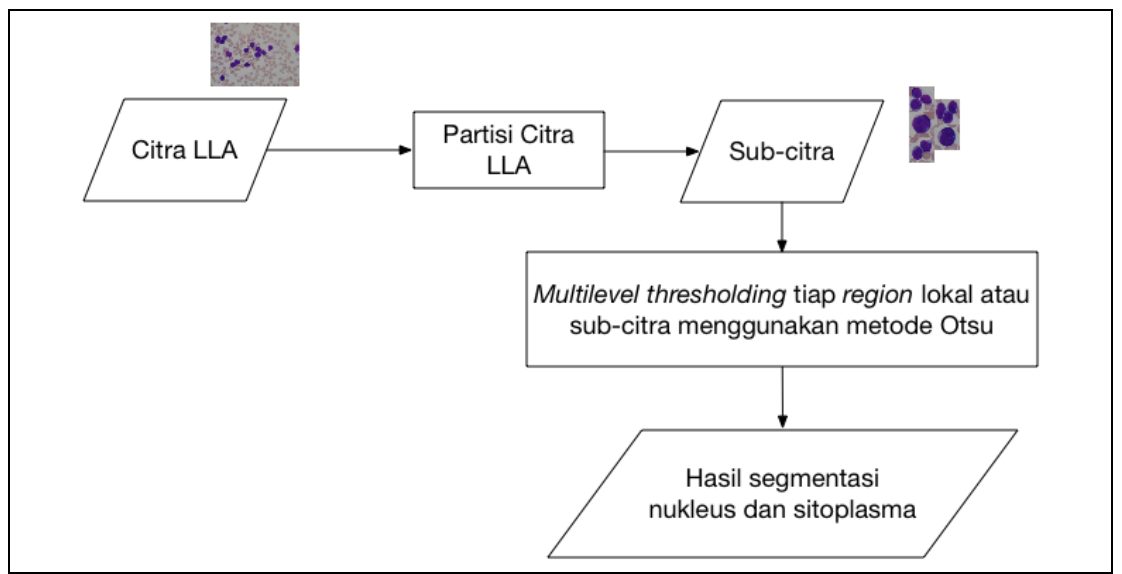

Gambar 2. Diagram metode yang diusulkan

\section{Metode Usulan}

Metode yang diusulkan terdiri dari dua fase: pertama-tama, citra input dipartisi menjadi sejumlah sub-citra. Selanjutnya, berdasarkan informasi histogram masing-masing sub-citra, three-level thresholding diaplikasikan menggunakan metode Otsu. Dua nilai ambang lokal digunakan untuk membagi citra ke dalam tiga bagian (three-level) yaitu nukleus, sitoplasma, dan latar belakang. Nilai ambang lokal adalah nilai ambang pada masing-masing sub-citra. Proses tersebut diulang hingga semua sub-citra tersegmentasi. Secara umum, metode yang diusulkan ditunjukkan oleh Gambar 2.

\subsection{Partisi Citra LLA}

Partisi citra LLA bertujuan untuk membagi citra LLA menjadi sub-sub citra, dengan tiap sub-citra berisi objek leukosit. Objek-objek yang akan dipartisi ditentukan berdasarkan prakiraan lokasi leukosit. Prakiraan lokasi leukosit paling mudah diketahui dari lokasi nukleusnya karena piksel nukleus memiliki karakteristik intensitas warna yang paling gelap dari semua piksel leukosit. Metode berbasis teori ortogonalisasi Gram-Schmidt digunakan untuk menentukan prakiraan lokasi leukosit.

Citra komposit prakiraan lokasi leukosit diperoleh dari inner product antara vektor bobot $w$ dengan intensitas warna RGB citra input. Vektor bobot $w$ diperoleh menggunakan teknik ortogonalisasi Gram-Schmidt yang ditunjukkan oleh Persamaan (1). Vektor $u_{1}$ dan $u_{2}$ didapat menggunakan Persamaan (2). Vektor $\mathrm{v}_{1}, \mathrm{v}_{2}$, dan $\mathrm{v}_{3}$ didefinisikan pada intensitas warna RGB citra. Vektor $\mathrm{v}_{1}$ merupakan rata-rata komponen $\mathrm{R}, \mathrm{G}$, dan $\mathrm{B}$ nukleus. Vektor $\mathrm{v}_{2}$, dan $\mathrm{v}_{3}$ merupakan rata-rata komponen $\mathrm{R}, \mathrm{G}$, dan $\mathrm{B}$ region sitoplasma dan latar belakang. Vektor $\mathrm{v}_{1}, \mathrm{v}_{2}$, dan $v_{3}$ diperoleh dari sebuah sampel citra LLA dan nilainya ditunjukkan pada Persamaan (3). 
Operator projeksi $\operatorname{proj}(u, v)$ adalah projeksi vektor $v$ pada vektor $u$ yang secara umum didefinisikan pada Persamaan (4).

$$
\begin{aligned}
& w=v_{3}-\operatorname{proj}\left(u_{1}, v_{3}\right)-\operatorname{proj}\left(u_{2}, v_{3}\right) \\
& u_{1}=v_{1} \\
& u_{2}=v_{2}-\operatorname{proj}\left(u_{1}, v_{2}\right) \\
& v_{1}=\left[\begin{array}{lll}
61 & 80 & 122
\end{array}\right] ; v_{2}=\left[\begin{array}{lll}
164 & 165 & 165
\end{array}\right] ; v_{3}=\left[\begin{array}{lll}
245 & 225 & 224
\end{array}\right] \\
& \operatorname{proj}(u, v)=\frac{\langle u, v\rangle}{\langle u, u\rangle} u=\langle u, v\rangle \frac{u}{\langle u, u\rangle}
\end{aligned}
$$

Inner product antara vektor bobot $w$ dengan vektor intensitas warna RGB citra input (Gambar 3a) menghasilkan citra komposit (Gambar 3b) yang memiliki intensitas warna maksimum (terang) pada region berwarna violet dan intensitas warna minimum (gelap) pada region lain. Nilai ambang sebesar 0.5 diaplikasikan pada citra komposit tersebut sehingga didapatkan citra prakiraan leukosit (Gambar 3c).

Misalkan citra prakiraan leukosit adalah $r(x, y)$, maka $r_{i}(x, y)$ adalah komponen terhubung (region-region) yang terdapat pada $r(x, y)$, dengan $i=1,2, \ldots, n ; n$ adalah jumlah region; atau $r_{i}(x, y) \in r(x, y)$. Berdasarkan citra prakiraan leukosit tersebut, diperoleh bounding box tiap $r_{i}(x, y)$. Bounding box adalah kotak imajiner yang mengelilingi $r_{i}(x, y)$. Bounding box tiap $r_{i}(x, y)$ ditentukan berdasarkan koordinat spasial piksel upper-left (UL), upper-right(UR), lower-left (LL), dan lower-right (LR). Misalkan ukuran citra $r_{i}(x, y)$ adalah $M \times N$, dengan $M$ adalah jumlah baris piksel dan $N$ adalah jumlah kolom piksel, maka ilustrasi bounding box $r_{i}(x, y)$ ditunjukkan oleh Gambar 3d dan Gambar 4. Alur penentuan bounding box tiap region $r_{i}(x, y)$ ditunjukkan oleh Gambar 5.

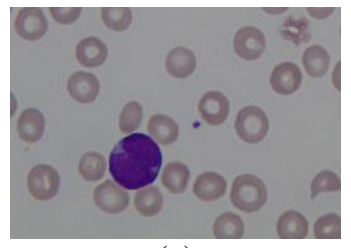

(a)

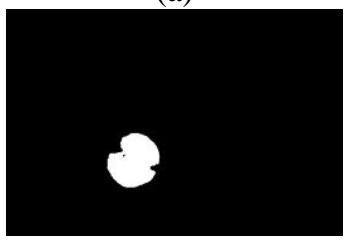

(c)

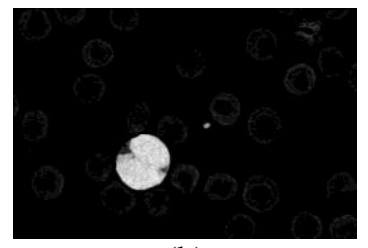

(b)

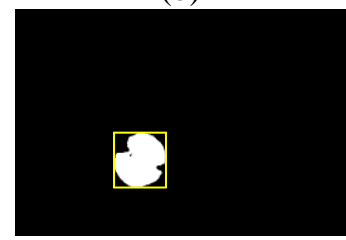

(d)

Gambar 3. (a) citra input (b) citra hasil inner product antara citra input RGB dengan vektor bobot $w$ yang dihitung menggunakan metode Gram-Schmidt (c) citra prakiraan leukosit setelah diaplikasikan nilai ambang sebesar 0.5 (d) bounding box komponen terhubung (region) ditunjukkan oleh kotak kuning

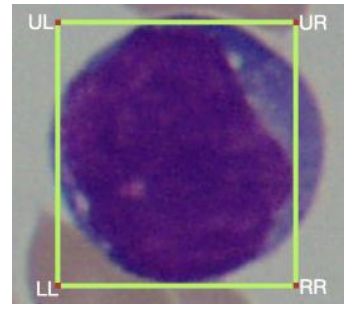

(a)

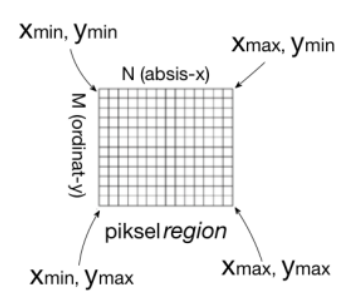

(b)

Gambar 4. Ilustrasi bounding box 


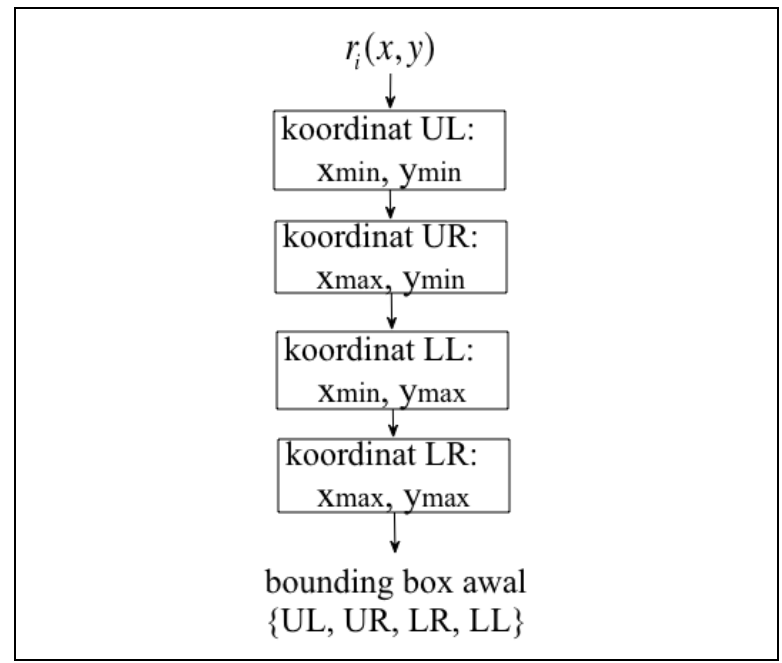

Gambar 5. Alur penentuan bounding box

Bounding box yang diperoleh tersebut hanya mengelilingi area nukleus (Gambar 6a). Untuk mencakup area seluruh sel, yaitu area nukleus dan sitoplasma, maka ukuran bounding box diatur kembali dengan melebarkannya. Masing-masing koordinat spasial bounding box (UL, UR, LL, LR) diperlebar dengan menambahkan $k$ piksel (Gambar 6b). Nilai $k=30$ diperoleh dari rata-rata lebar piksel sitoplasma. Partisi citra LLA menjadi sub-sub citra dilakukan berdasarkan bounding box yang telah diperlebar. Gambar 7 mengilustrasikan sub-citra yang telah dipartisi.

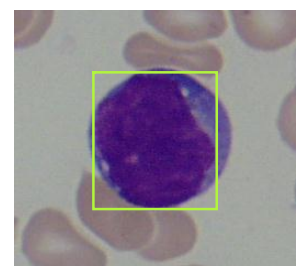

(a)

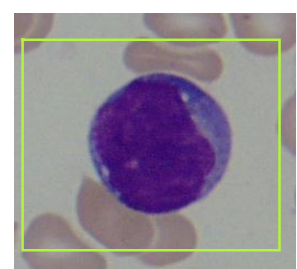

(b)

Gambar 6. (a) bounding box sebelum diperlebar. (b) bounding box setelah diperlebar ukurannya sebesar $k$ piksel, $k=30$

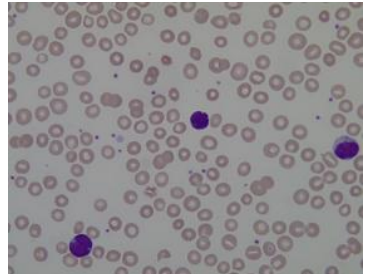

(a)

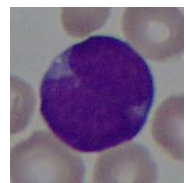

Gambar 7. (a) citra input (b) sub-citra

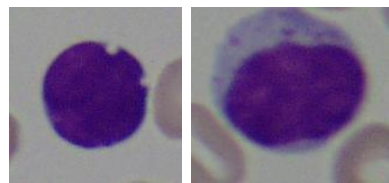

(b)

\subsection{Three-level Thresholding Sub-citra menggunakan Metode Otsu}

Three-level thresholding mensegmentasi sub-citra dengan dua nilai ambang lokal (masing-masing sub-citra) yang membagi piksel citra ke dalam tiga region yaitu latar belakang, nukleus dan sitoplasma. Nilai ambang lokal ditentukan pada komponen $b^{*}$ dari ruang warna CIE Lab. Komponen $b^{*}$ dalam ruang warna CIE Lab dipilih selain untuk mengurangi pengaruh iluminasi citra, juga dipilih karena region leukosit cenderung berwarna biru sehingga dapat dibedakan dari latar belakang.

Metode Otsu yang digunakan untuk menentukan sebuah nilai ambang yang membagi piksel ke dalam dua kelas (bi-level), dapat diturunkan untuk kasus segmentasi yang membagi 
piksel ke dalam tiga kelas (three-level) menggunakan nilai ambang jamak (lebih dari sebuah nilai ambang). Pendekatan Otsu tersebut berbasis histogram, yaitu informasi yang didapat dengan mudah dari sebuah citra. Pada penelitian ini, dua nilai ambang yang membagi region sub-citra menjadi tiga kelas digunakan, nilai ambang jamak diperoleh ketika varian masing-masing kelasnya maksimum.

Metode Otsu untuk kasus three-level thresholding didemonstrasikan oleh Persamaan (5), dengan ${ }^{2}$ adalah varian antar kelas, th adalah nilai ambang, $\quad{ }_{i}$ dan ${ }_{i}$ menyatakan jumlah kumulatif probabilitas kemunculan gray-level dan rata-rata kumulatifnya untuk kelas ke-i, sedangkan ${ }_{T}$ merupakan penjumlahan hasil kali jumlah kumulatif probabilitas kemunculan gray-level dan rata-rata kumulatifnya dari tiap kelas. Nilai ${ }_{i}$ dan ${ }_{i}$ diperoleh menggunakan Persamaan (6) dan Persamaan (7), dengan $H$ adalah histogram distribusi intensitas piksel citra, $h(s)$ adalah jumlah piksel gray-level $s$ pada histogram $H, N p$ adalah jumlah piksel sub-citra, $\min (H)$ dan $\max (H)$ adalah intensitas minimum dan maksimum gray-level pada histogram $H$, dan $P(s)$ adalah probabilitas kemunculan gray-level $s$ pada histogram $h(s)$ yang dihitung menggunakan Persamaan (8). $T_{T}$ dihitung menggunakan Persamaan (9). Metode Otsu kemudian mencari nilai ambang th optimal yang memaksimumkan varian antar kelas 2 (Persamaan (10)), dengan $t h_{1}$ dan $t h_{2}$ adalah nilai ambang optimalnya.

$$
\begin{aligned}
& \sigma^{2}(t h)=\sum_{i=1}^{3} \sigma_{i}=\sum_{i=1}^{3} \omega_{i}\left(\mu_{i}-\mu_{T}\right)^{2} \\
& \omega_{1}(t h)=\sum_{s=\min (H)}^{t h_{1}} P(s), \omega_{2}(t h)=\sum_{s=t h_{1}+1}^{t h_{2}} P(s), \omega_{3}(t h)=\sum_{s=t h_{2}+1}^{\max (H)} P(s) \\
& \mu_{1}=\sum_{s=\min (H)}^{t h_{1}} \frac{s P(s)}{\omega_{1}(t h)}, \mu_{2}=\sum_{s=t h_{1}+1}^{t h_{2}} \frac{s P(s)}{\omega_{2}(t h)}, \mu_{3}=\sum_{s=t h_{2}+1}^{\max (H)} \frac{s P(s)}{\omega_{3}(t h)} \\
& P(s)=\frac{h(s)}{N p}, \sum_{i=1}^{N p} P(s)=1 \\
& \mu_{T}=\sum_{i=1}^{3} \omega_{i} \mu_{i} \\
& t h_{1}, t h_{2}=\operatorname{Arg}\left(\operatorname{Max}_{\min (H) \leq t h \leq \max (H)}\left\{\sigma^{2}(t h)\right\}\right)
\end{aligned}
$$

\subsubsection{Ekstraksi Nukleus dan Sitoplasma}

Region nukleus dan sitoplasma dari citra LLA diperoleh berdasarkan nilai ambang lokal $t h_{1}$ dan $t h_{2}$, menggunakan Persamaan (11), dengan $g(x, y)$ adalah intensitas piksel sub-citra, $R 1$ dan $R 2$ adalah region nukleus dan sitoplasma, sedangkan $R 3$ adalah piksel latar belakang. Gambar 8c dan Gambar 8d masing-masing adalah region sitoplasma dan nukleus tiap sub-citra (Gambar 8b) dari citra LLA (Gambar 8a). Hasil thresholding citra LLA ditunjukkan oleh Gambar 8e. Pada Gambar 8e, nukleus ditandai oleh warna hitam, sedangkan sitoplasma ditandai warna keabuan.

$$
g(x, y)= \begin{cases}R 1 & \text { bila } g(x, y) \leq t h_{1} \\ R 2 & \text { bila } g(x, y) \leq t h_{2} \\ R 3 & \text { bila } g(x, y)>t h_{2}\end{cases}
$$

\subsubsection{Identifikasi dan Pemisahan Touching Cell}

Permasalahan pada citra leukemia adalah kehadiran sitoplasma yang saling bersentuhan (touching cell) atau grup sel, sehingga pemisahan grup sel tersebut perlu dilakukan. Untuk 
mendeteksi region yang termasuk touching cell digunakan pengukuran roundness sel karena touching cell dapat diidentifikasi melalui analisis bentuk. Roundness dihitung menggunakan Persamaan (12). Sel yang tidak bersentuhan berbentuk lebih bundar daripada touching cell.

roundness $=\frac{4 * \pi * \text { area }}{\text { perimeter }}{ }^{2}$

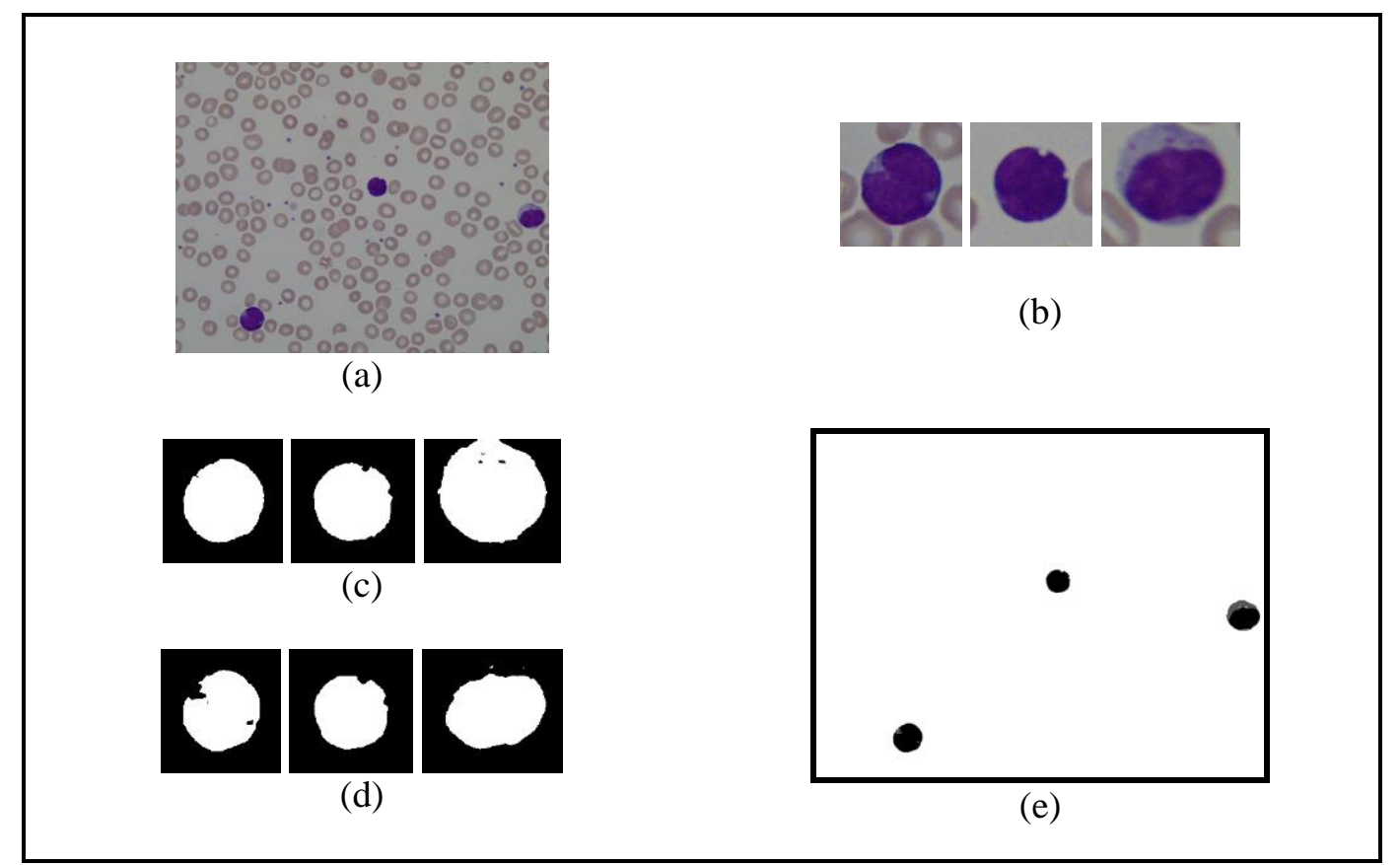

Gambar 8. (a) citra original (b) sub-citra (c) hasil thresholding sitoplasma (d) hasil thresholding nukleus (e) hasil thresholding sub-citra digabungkan

Roundness menyatakan circularity objek, yaitu rasio antara area dengan perimeter. Roundness bernilai satu untuk objek yang berbentuk bundar, sedangkan bernilai kurang dari satu untuk objek yang menjauhi bentuk bundar. Pada penelitian ini digunakan nilai ambang roundness sebesar 0,8 untuk memisahkan region yang merupakan touching cell dan yang bukan touching cell seperti yang dilakukan oleh (Putzu, dkk., 2014). Region sitoplasma dengan roundness lebih besar dari nilai ambang diklasifikasikan sebagai sel non-touching (individual), sedangkan region sitoplasma dengan roundness kurang dari nilai ambang diklasifikasikan sebagai touching cell. Proses ini membagi citra menjadi dua bagian. Hanya citra yang diklasifikasikan sebagai touching cell yang akan diproses selanjutnya untuk pemisahan. Pemisahan touching cell dilakukan menggunakan algoritma segmentasi watershed berbasis transformasi jarak euclidean. Hasil identifikasi dan pemisahan touching cell ditunjukkan oleh Gambar 9.

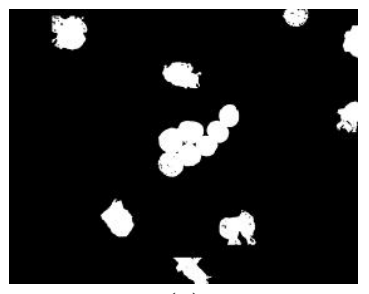

(a)

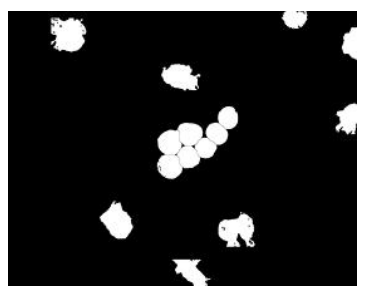

(b)

Gambar 9. Identifikasi dan pemisahan touching cell (a) identifikasi touching cell (b) hasil pemisahan menggunakan algoritma watershed 


\subsubsection{Image Cleaning}

Image cleaning terdiri dari penghapusan semua region sel darah putih yang terdapat pada tepi citra dan semua komponen abnormal (region sel darah putih cacat pewarnaan), bertujuan untuk mengurangi error pada tahap klasifikasi. Penghapusan citra yang berada di tepi merupakan operasi sederhana, sedangkan penghapusan komponen abnormal merupakan proses yang lebih kompleks karena membutuhkan analisis geometri region sel darah putih. Pertama, ukuran area dan convex area dihitung untuk masing-masing sel darah putih. Selanjutnya kombinasi area dan convex area digunakan untuk menghitung nilai solidity yang digunakan untuk memisahkan komponen abnormal. Solidity mengukur kepadatan objek. Solidity didefinisikan sebagai rasio antara objek area dengan area convex hull objek (Persamaan (13)).

$$
\text { solidity }=\frac{\text { area }}{\text { convex_area }}
$$

Nilai solidity 1 menandakan objek yang solid, dan nilai kurang dari 1 menandakan objek dengan boundary irregular (atau terdapat holes). Nilai ambang solidity yang digunakan pada penelitian ini berdasar pada metode usulan (Putzu, 2014) yaitu 0,9. Semua objek bernilai solidity di bawah nilai ambang akan dihapus. Hasil segmentasi nukleus dan sitoplasma ditunjukkan oleh Gambar 10.

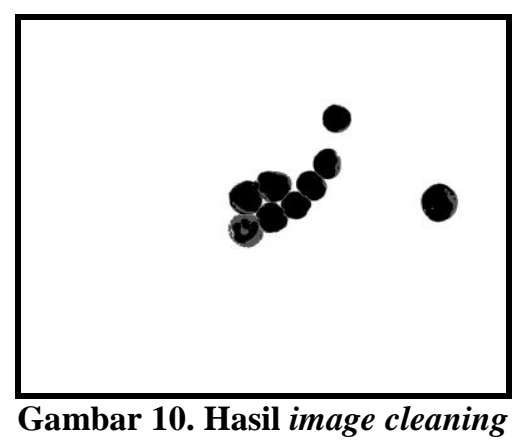

\section{Hasil Uji Coba \\ 4.1. Data Uji Coba}

Untuk mengetahui performa metode three-level local thresholding (TLTH), digunakan sebanyak 32 citra uji yang diperoleh dari basis data ALL-IDB1, yang disediakan oleh (Labati, 2011). Citra uji tersebut terdiri dari sel-sel LLA dan non-LLA dengan resolusi citra 1712x1368 piksel. Beberapa sel LLA dijumpai dalam grup sel atau touching cell. Hasil segmentasi dari metode usulan dibandingkan dengan citra yang disegmentasi secara manual. Citra yang disegmentasi secara manual tersebut dianggap sebagai hasil segmentasi yang benar (ground truth). Perhitungan manual jumlah sel darah putih berdasar pada jumlah sel limfosit yang dicantumkan pada file xyc yang disertakan dalam basis data citra, ditambah dengan jumlah sel non-limfosit yang diidentifikasi berdasarkan pengamatan manusia (manual).

\subsection{Evaluasi Hasil Segmentasi}

Hasil segmentasi metode yang diusulkan dibandingkan dengan citra ground truth yang disegmentasi manual yang bertujuan untuk mengklasifikasikan piksel ROI sel darah putih sebagai true positive, false negative, atau false positive, yang direpresentasikan ke dalam Zijdenbos Similarity Index (ZSI), presisi, dan recall. ZSI didefinisikan sebagai rasio dua kali interseksi area antara hasil segmentasi dan citra ground truth dengan jumlah dari keduanya. ZSI dihitung menggunakan Persamaan (14), dengan A merepresentasikan piksel hasil segmentasi metode yang diusulkan dan $\mathrm{G}$ merepresentasikan piksel citra ground truth. Dengan menggunakan true positive (TP), false negative (FN), dan false positive $(\mathrm{FP})$, presisi $(\mathrm{P})$ dan recall (R) dapat dihitung menggunakan Persamaan (15). 


$$
\begin{gathered}
Z S I=\frac{2 \times|A \cap G|}{|A|+|G|} \\
P=\frac{T P}{T P+F P} \\
R=\frac{T P}{T P+F N}
\end{gathered}
$$

Nilai ZSI yang lebih besar dari 0,7 mengindikasikan similaritas tinggi yaitu kemiripan (good match) antar dua region. Presisi dapat merepresentasikan over-segmentation, sedangkan recall atau bisa disebut juga sensitivitas dapat merepresentasikan under-segmentation.

\subsubsection{Hasil Uji Coba Perbandingan Akurasi Metode Usulan dengan Metode Three-level Global Thresholding}

Tabel 1 dan Tabel 2 menunjukkan perbandingan rata-rata akurasi hasil segmentasi sitoplasma dan nukleus (presisi $(\mathrm{P})$, recall $(\mathrm{R})$, dan ZSI) menggunakan metode yang diusulkan (TLTH) dan metode three-level global thresholding (TGTH). TLTH dan TGTH menggunakan dua nilai ambang yang ditentukan pada komponen $b^{*}$ dalam ruang warna CIE Lab. Pada TGTH, nilai ambang ditentukan berdasarkan histogram keseluruhan piksel citra LLA. Baik pada TLTH maupun TGTH, ekstraksi region sitoplasma dan nukleus menggunakan Persamaan (11). Gambar 12 menunjukkan contoh perbandingan hasil segmentasi metode TLTH dan TGTH. Region nukleus ditunjukkan dengan warna hitam, sedangkan sitoplasma dengan warna keabuan.

Tabel 1. Rata-rata Akurasi Hasil Segmentasi Sitoplasma beserta Standar Deviasinya

\begin{tabular}{cccc}
\hline & \multicolumn{3}{c}{ Akurasi Segmentasi Sitoplasma } \\
\cline { 2 - 4 } & Presisi & Recall & ZSI \\
\hline TLTH & $0.911 \pm 0.0744$ & $0.938 \pm 0.1005$ & $0.920 \pm 0.0727$ \\
\hline TGTH & $0.162 \pm 0.1814$ & $0.997 \pm 0.0057$ & $0.244 \pm 0.2291$ \\
\hline
\end{tabular}

Tabel 2. Rata-rata Akurasi Hasil Segmentasi Nukleus beserta Standar Deviasinya

\begin{tabular}{cccc}
\hline & \multicolumn{3}{c}{ Akurasi Segmentasi Nukleus } \\
\cline { 2 - 4 } & Presisi & Recall & ZSI \\
\hline TLTH & $0.911 \pm 0.080$ & $0.940 \pm 0.083$ & $0.922 \pm 0.066$ \\
\hline TGTH & $0.640 \pm 0.154$ & $0.998 \pm 0.002$ & $0.769 \pm 0.120$ \\
\hline
\end{tabular}

Berdasarkan Tabel 1, performa hasil segmentasi sitoplasma menggunakan metode yang diusulkan memiliki rata-rata presisi tertinggi dibandingkan dengan hasil segmentasi sitoplasma menggunakan metode TGTH, yaitu sebesar 0.911. Begitu pula dengan ZSI rata-rata, metode yang diusulkan pada penelitian ini memiliki nilai tertinggi dibandingkan TGTH yaitu sebesar 0.92, sedangkan recall tertinggi diperoleh oleh TGTH. Meskipun segmentasi sitoplasma dengan TGTH memiliki nilai recall tinggi, namun presisinya rendah, hanya 0.162 , yang berarti rasio false positive yang tinggi, sehingga rata-rata hasilnya over-segmentation.

Pada Tabel 2, dibuktikan bahwa hasil segmentasi nukleus menggunakan metode yang diusulkan juga memiliki rata-rata presisi tertinggi dibandingkan dengan hasil segmentasi nukleus menggunakan TGTH, yaitu sebesar 0.911. Begitu pula dengan ZSI rata-rata, metode yang diusulkan pada penelitian ini memiliki nilai tertinggi dibandingkan TGTH yaitu sebesar 0.922 , sedangkan recall tertinggi diperoleh oleh TGTH. Sebagai tambahan, rata-rata akurasi (recall, presisi, dan ZSI) segmentasi nukleus, baik menggunakan TLTH maupun TGTH, lebih tinggi dibandingkan rata-rata akurasi segmentasi sitoplasmanya karena jumlah piksel nukleus lebih banyak dibandingkan sitoplasma sekaligus memiliki intensitas warna yang sebagian besar homogen terutama sel-sel limfosit.

Namun demikian, pada citra yang ditunjukkan oleh Gambar 12 pada baris pertama, teknik three-level global thresholding menghasilkan hasil segmentasi terbaik dari semua citra. Citra tersebut memiliki jumlah piksel leukosit dibanding piksel latar belakang dan eritrosit lebih 
banyak dibandingkan citra uji lainnya. Ini membuktikan bahwa teknik TGTH berhasil mensegmentasi citra LLA dengan baik bila jumlah piksel leukosit sebanding dengan jumlah piksel latar belakang dan eritrosit. Hal yang berbeda ditunjukkan oleh Gambar 12 pada baris kedua dan ketiga, teknik TGTH tidak dapat mensegmentasi sitoplasma dan nukleus dengan baik bila jumlah pikselnya hanya bagian kecil dari total piksel citra LLA.

\subsubsection{Hasil Uji Coba Pemisahan Touching Cell}

Untuk mengetahui performa algoritma watershed dalam pemisahan touching cell, jumlah sel tunggal hasil pemisahan algoritma watershed dan jumlah sel tunggal yang dihitung secara manual pada touching cell dibandingkan. Perbandingan perhitungan jumlah sel tunggal pada touching cell menggunakan watershed dengan perhitungan manual dapat dilihat dalam Tabel 3.

Tabel 3. Perbandingan perhitungan jumlah sel tunggal menggunakan algoritma watershed dengan perhitungan manual

\begin{tabular}{lcc}
\hline \multirow{2}{*}{ itra } & Jumlah sel tunggal pada touching cell \\
\cline { 2 - 3 } & Watershed & Manual \\
\hline $\operatorname{Im} 1$ & 7 & 7 \\
\hline $\operatorname{Im} 3$ & 8 & 8 \\
\hline $\operatorname{Im} 4$ & 5 & 5 \\
\hline $\operatorname{Im} 5$ & 11 & 11 \\
\hline $\operatorname{Im} 6$ & 14 & 14 \\
\hline $\operatorname{Im} 7$ & 5 & 5 \\
\hline $\operatorname{Im} 8$ & 10 & 10 \\
\hline $\operatorname{Im} 9$ & 2 & 2 \\
\hline $\operatorname{Im} 10$ & 4 & 4 \\
\hline $\operatorname{Im} 11$ & 5 & 5 \\
\hline $\operatorname{Im} 12$ & 4 & 4 \\
\hline $\operatorname{Im} 13$ & 6 & 6 \\
\hline $\operatorname{Im} 14$ & 3 & 3 \\
\hline $\operatorname{Im} 15$ & 12 & 12 \\
\hline $\operatorname{Im} 16$ & 4 & 4 \\
\hline $\operatorname{Im} 17$ & 3 & 3 \\
\hline $\operatorname{Im} 18$ & 5 & 5 \\
\hline $\operatorname{Im} 19$ & 7 & 9 \\
\hline
\end{tabular}

Tabel 3 membuktikan bahwa hasil pemisahan touching cell menggunakan algoritma segmentasi watershed menggunakan transformasi jarak euclidean, memberikan hasil yang sangat baik. Hal berbeda ditunjukkan oleh citra Im19, hanya 7 dari 9 sel yang berhasil dipisahkan. Untuk menganalisisnya, Gambar 11 memberikan ilustrasinya. Pada Gambar 11, rectangle merah yang mengelilingi salah satu area pada region touching cell, menunjukkan bahwa pada area tersebut tidak terdapat area pemisah antar tiga sel tunggal, sehingga algoritma watershed menganggap catchment basin berada di tengah sel. Hal tersebut berakibat tiga sel tidak dapat dipisahkan.

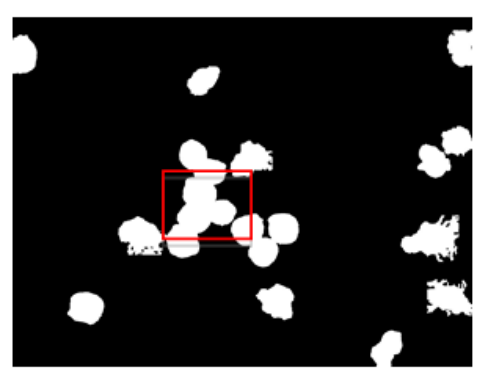

Gambar 11. Citra Im19 sebelum proses pemisahan touching cell 


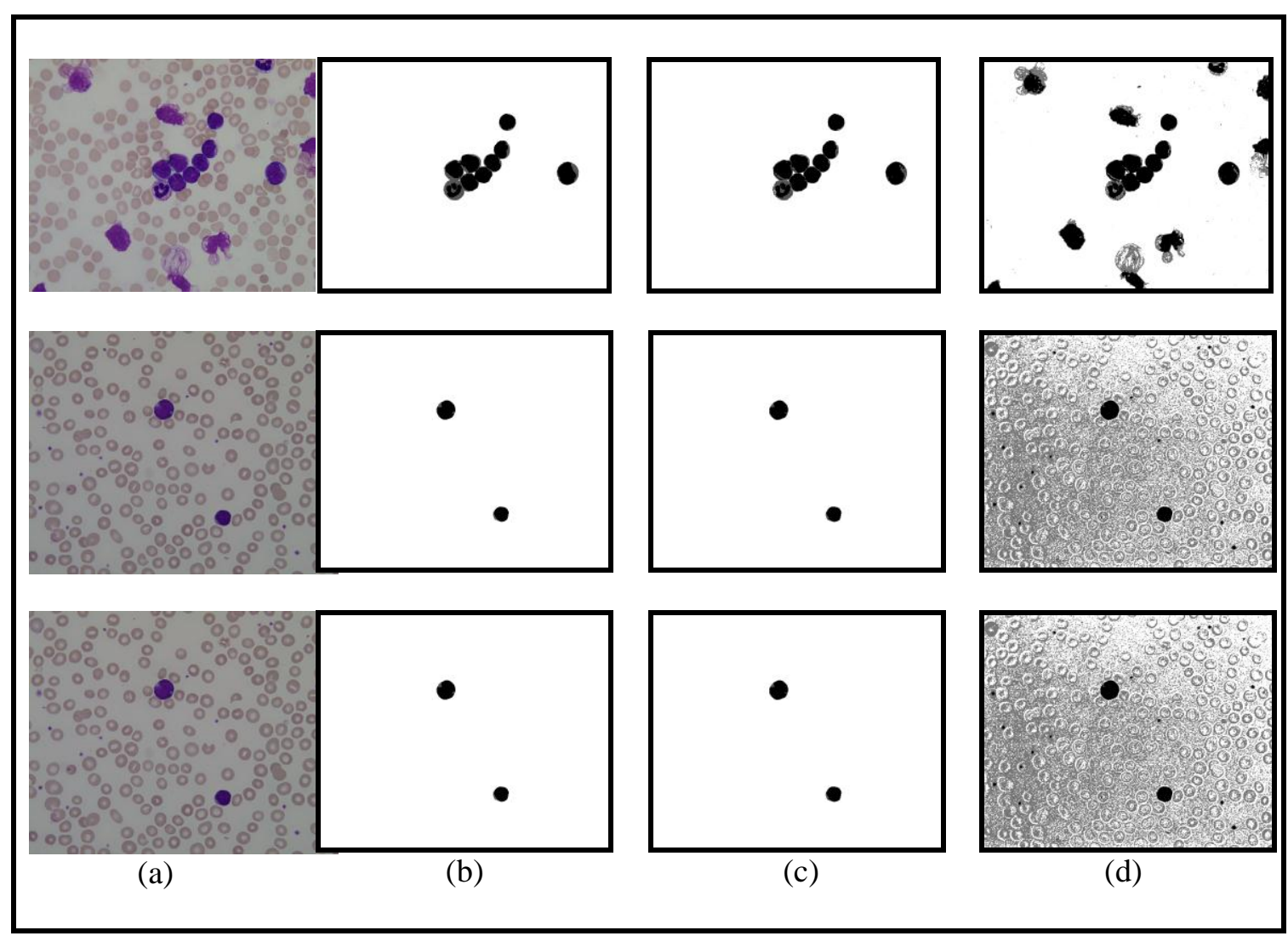

Gambar 12. Hasil Uji Coba Segmentasi Leukosit (a) Citra original (b) citra ground truthnya (c) TLTH dan (d) TGTH

\section{Kesimpulan dan Saran}

Three-level local thresholding berbasis metode Otsu diusulkan untuk meningkatkan akurasi segmentasi nukleus dan sitoplasma. Metode yang diusulkan, pertama-tama melakukan partisi citra berdasarkan prakiraan leukosit, yang mudah didapat dari lokasi di sekitar nukleus. Teknik local thresholding menggunakan dua nilai ambang yang membagi citra ke dalam tiga level (three-level) diaplikasikan pada masing-masing sub-citra hasil partisi citra untuk segmentasi nukleus dan sitoplasma. Performa metode yang diusukan diuji menggunakan 32 citra uji LLA. Hasil segmentasinya dibandingkan dengan citra yang disegmentasi manual. Hasil uji coba membuktikan bahwa akurasi metode usulan lebih tinggi $277,05 \%$ dibandingkan metode TGTH. Keunggulan metode yang diusulkan (TLTH) yaitu bila terdapat situasi jumlah piksel region leukosit, sitoplasma maupun nukleus, yang merupakan bagian kecil daripada pikselpiksel objek selainnya, TLTH mampu mensegmentasi lebih baik daripada teknik global thresholding.

Penelitian selanjutnya diharapkan mengembangkan metode ini dengan jumlah nilai ambang yang adaptif, disesuaikan dengan distribusi intensitas tiap sub-citra, untuk memperbaiki hasil segmentasi sel non-limfosit, misalnya basofil atau neutrofil.

\section{Referensi}

Albitar, M., Giles, F.J. \& Kantarjian, H.M. 2008. Diagnosis of Acute Lymphoblastic Leukemia. Dalam E.H. Estey, S.H. Faderl, dan H.M. Kantarjian (Eds.), Acute Leukemias (hlm. 119130). New York: Springer Berlin Heidelberg.

Fatichah, C., Tangel, M. L., Widyanto, M. R., Dong, F., \& Hirota, K. 2012. Interest-Based Ordering for Fuzzy Morphology on White Blood Cell Image Segmentation. JACIII, 16, (1): 76-86. 
Gao, H., Xu, W., Sun, J., \& Tang, Y. 2010. Three-level thresholding for image segmentation through an improved quantum-behaved particle swarm algorithm. Instrumentation and Measurement, IEEE Transactions on, 59(4): 934-946.

Labati, R. D., Piuri, V., \& Scotti, F. 2011,“All-IDB: The Acute Lymphoblastic Leukemia Image Database for Image Processing", Proceedings of the 18th IEEE ICIP International Conference on Image Processing, Eds: Macq, B., dan Schelkens, P.,IEEE Signal Processing Society, Brussels, hal. 2045-2048.

Larson, R.A. \& Anastasi, J. 2008. Acute Lymphoblastic Leukemia: Clinical Presentation, Diagnosis, and Classification. Dalam E.H. Estey, S.H. Faderl, dan H.M. Kantarjian (Eds.), Acute Leukemias (hlm. 109-118). New York: Springer Berlin Heidelberg.

Madhloom, H. T., Kareem, S. A., \& Ariffin, H. 2012. An Image Processing Application for the Localization and Segmentation of Lymphoblast Cell using Peripheral Blood Images. Journal of medical systems, 36(4): 2149-2158.

Mohapatra, S., Patra, D., \& Satpathy, S. 2014. An Ensemble Classifier System for Early Diagnosis of Acute Lymphoblastic Leukemia in Blood Microscopic Images. Neural Computing and Applications, 24(7-8): 1887-1904.

Piuri, V., \& Scotti, F. (2004), "Morphological Classification of Blood Leucocytes by Microscope Images", Proceedings of the 2004 IEEE International Conference on Computational Intelligence for Measurement Systems and Applications, Eds: Alippi, C. et al., IEEE, Boston, hal. 103-108.

Putzu, L., Caocci, G., \& Di Ruberto, C. 2014. Leucocyte Classification for Leukaemia Detection using Image Processing Techniques. Artificial Intelligence in Medicine, 62(3): 179-191.

Rezatofighi, S. H. \& Soltanian-Zadeh, H. 2011. Automatic Recognition of Five Types of White Blood Cells in Peripheral Blood. Computerized Medical Imaging and Graphics, 35(4): 333-343.

Scotti, F. (2006), "Robust Segmentation and Measurements Techniques of White Cells in Blood Microscope Images", Proceedings of the 2006 IEEE Instrumentation and Measurement Technology Conference, Eds: Daponte, P. et al., IEEE Instrumentation and Measurement Society, Sorrento, hal. 43-48.

Wang, E. Y., Gou, Z., Miao, A. M., Peng, S. Q., Niu, Z. Y., \& Shi, X. L. (2009), "Recognition of Blood Cell Images based on Color Fuzzy Clustering", dalam Fuzzy Information and Engineering Volume 2, eds. Cao, B., Li, T., dan Zhang, C., Springer Berlin Heidelberg, New York, hal. 69-75. 